\title{
Hubungan Obesitas dan Stress Oksidatif
}

\section{Zulfahmidah $^{1}$, Fajriansyah ${ }^{* 2}$, Armanto Makmun $^{3}$, Rasfahyana ${ }^{1}$}

${ }^{1}$ Bagian Biokimia, Fakultas Kedokteran, Universitas Muslim Indonesia, Makassar

${ }^{2}$ Depertemen Farmakologi, Sekolah Tinggi Ilmu Farmasi, Makassar

${ }^{3}$ Bagian Ilmu Kesehatan Masyarakat, Fakultas Kedokteran, Universitas Muslim Indonesia, Makassar

*Corresponding Author. E-mail: fajrin.fajriansyah@yahoo.com Mobile number: 082345319900

\begin{tabular}{|l|} 
ABSTRAK \\
Latar Belakang: Pada tahun 2016, lebih dari 1,9 miliar manusia dewasa berusia diatas 18 tahun menderita \\
kelebihan berat badan dan $>650$ juta diantaranya menderita obesitas. Menurut hasil riset kesehatan dasar atau \\
Riskesdas 2018 tingkat obesitas pada orang dewasa di Indonesia meningkat menjadi 21,8 persen. Prevalensi ini \\
meningkat dari hasil Riskesdas 2013 yang menyebut bahwa angka obesitas di Indonesia hanya mencapai 14,8 \\
persen. \\
Hasil: Obesitas dapat menimbukan keadaan yang dinamakan stres oksidatif yaitu merupakan keadaan dimana \\
terjadi peningkatan radikal bebas yang tidak diimbangi oleh peningkatan antioksidan di dalam tubuh. Terdapat \\
beberapa kondisi pada obesitas yang dapat memicu stress oksidatif, diantaranya: Hiperglikemik, hiperlipidemia, \\
chronic low grade inflammation, hiperleptinemia, peningkatan aktifitas otot, dan disfungsi endotelial. \\
Kesimpulan: Stres oksidatif pada obesitas menyebabkan kerusakan sel yang memegang peranan penting dalam \\
pathogenesis penyakit-penyakit degeneratif seperti hipertensi, diabetes mellitus, kanker, dan proses penuaan \\
Kata Kunci: Obesitas; stres oksidatif
\end{tabular}

Article history:

Received: 10 April 2021

Accepted: 30 April 2021

Published: 30 Juni 2021

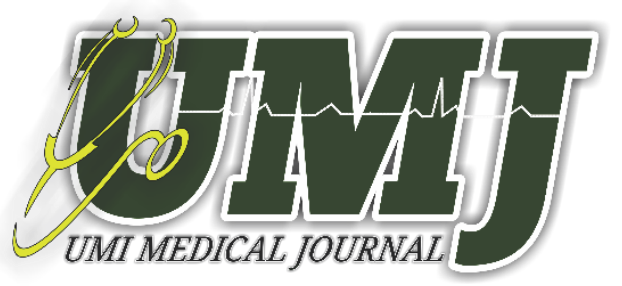

Published by :

Fakultas Kedokteran

Universitas Muslim Indonesia

Phone:

+6282293330002
Address:

Jl. Urip Sumoharjo Km. 5 (Kampus II UMI)

Makassar, Sulawesi Selatan.

Email:

medicaljournal@umi.ac.id 


\section{ABTRACT}

Background: Obesity is a condition where there is accumulation of excess fat in the body. In 2016, more than 1.9 billion adult humans over the age of 18 were overweight and $>650$ million were obese. According to the results of Riskesdas 2018, the rate of obesity in adults in Indonesia has increased to 21.8 percent. This prevalence increased from the results of the 2013 Riskesdas which stated that the obesity rate in Indonesia only reached 14.8 percent. Results: In a state of obesity, oxidative stress may arise due to an imbalance of prooxidants and antioxidants in the body. Several conditions in obesity that can support oxidative stress, including: hyperglycemic, hyperlipidemia, low-grade chronic inflammation, hyperleptinemia, increased muscle activity, and endothelial dysfunction.

Conclusion: Oxidative stress in obesity causes cell damage which plays an important role in the pathogenesis of various degenerative disease such as diabetes mellitus, hypertension, the aging process, and cancer.

Keywords: Obesity; Oxidative stress

\section{PENDAHULUAN}

Obesitas merupakan suatu keadaan dimana terjadi lemak berlebih yang menumpuk dalam tubuh. Kegemukan ditandai dengan beberapa perubahan metabolik seperti resistensi insulin, dislipidemia, dan hipertensi. Penyakit yang timbul akibat obesitas seperti diabetes tipe 2 (T2D), penyakit kardiovaskular dan kanker tertentu, semakin meningkat penyebab penting morbiditas dan mortalitas. Dalam dekade terakhir, jumlah yang sangat besar penelitian telah didedikasikan untuk mempelajari patofisiologi kompleks obesitas dan untuk penelitian terapi medis baru. Berbagai penyakit degeneratif seperti penyakit jantung dan stroke disebabkan oleh obesitas. Pada lansia, penyakit-penyakit degeneratif tersebut merupakan penyebab kematian terbesar di dunia. Adanya penumpukan lemak di pembuluh darah dapat menyebabkan terjadinya penyumbatan aliran darah yang dapat berakibat fatal pada kehidupan $(1,2)$

Pada tahun 2016, lebih dari 1,9 miliar manusia dewasa berusia diatas 18 tahun menderita kelebihan berat badan dan >650 juta diantaranya menderita obesitas. Menurut hasil riset kesehatan dasar atau Riskesdas 2018 tingkat obesitas pada orang dewasa di Indonesia meningkat menjadi 21,8 persen. Prevalensi ini meningkat dari hasil Riskesdas 2013 yang menyebut bahwa angka obesitas di Indonesia hanya mencapai 14,8 persen. Obesitas sendiri mengacu pada kondisi di mana indeks massa tubuh diatas 27. Begitu juga dengan prevalensi berat badan berlebih dengan indeks massa tubuh antara 25 hingga 27 , juga meningkat dari 11,5 persen di 2013 ke 13,6 persen di 2018.(1)

Akumulasi lipid berlebihan pada obesitas dapat menyebabkan peningkatan produksi radikal bebas baik di sirkulasi maupun di sel adiposit. Peningkatan radikal bebas ini tidak diikuti oleh peningkatan enzim antioksidan dalam tubuh sehingga menyebabkan suatu kondisi yang disebut stress oksidatif. ROS menyebabkan banyak kerusakan dari tingkat sel, hingga jaringan. Salah satunya adalah membran plasma. Peningkatan ROS menyebabkan lipid peroksidasi pada membran plasma. (3) 
UMI Medical Journal Vol.6 Issue:1 (Juni, 2021)

p-ISSN: 2548-4079/e-ISSN: 2685-7561

\section{Aspek Biomolekular Obesitas}

AMP-Activated Protein Kinase (AMPK) dikenal sebagai regulator utama sel dan metabolisme di seluruh tubuh dalam beberapa tahun terakhir. Banyak jurnal yang melaporkan bahwa AMPK berperan dalam regulasi nafsu makan, berat badan, dan metabolisme [3-5]. Sehingga wajar bila AMPK disebut berkembang penting dalam perkembangan obesitas. Kompleks AMPK merupakan serin / treonin heterotrimer kinase yang terdiri dari subunit alfa, beta, dan gamma. AMPK dapat aktif bila stres seluler terjadi, dimana deplesi ATP seluler menyebabkan peningkatan AMP. AMP dapat mengaktifkan AMPK dengan tiga mekanisme berbeda: (a) aktivasi alosterik, (b) stimulasi fosforilasi subunit alfa di Thr172 oleh kinase dan (c) penghambatan defosforilasi oleh protein fosfatase. Stress seluler yang menyebabkan kenaikan rasio AMP / ATP dapat disebabkan oleh racun metabolik (arsenit, oligomisin), stress oksidatif, hipoksia, hipoglikemia, kontraksi otot dan kekurangan nutrisi. Osmotik stres juga dapat mengaktifkan AMPK bahkan tanpa perubahan rasio AMP / ATP. Setelah diaktifkan, AMPK akan menghambat jalur anabolik seperti glukoneogenesis, sintesis glikogen, asam lemak, trigliserida, kolesterol dan protein (jalur mTOR-p70SK-E2), dan mengaktifkan jalur katabolik seperti glikolisis, pengambilan glukosa, dan oksidasi asam lemak. Pengaktifan dari AMPK juga memicu biogenesis mitokondria, yang meningkatkan kapasitas sintesis ATP di sel. Adanya aktivitas dari AMPK yang abnormal ini akan menyebabkan ketidakseimbangan energi yang kemudian berujung pada keadaanobesitas maupun DM tipe 2.

\section{ROS (Reactive Oxygen Species) sebagai Penyebab Kerusakan Sel}

Stress oksidatif berhubungan dengan banyak keadaan patologis seperti penyakit kardiovaskuler, kanker, dan lain-lain. Stress Oksidatif merupakan keadaan dimana terjadi peningkatan radikal bebas yang tidak diimbangi oleh peningkatan antioksidan di dalam tubuh. Hal ini membuat sel tidak berfungsi sebagai mestinya. Terjadi kerusakan pada sel terutama kerusakan pada lemak, protein, dan DNA. Perubahan struktur kimia DNA dapat terjadi bila ada interaksi antara ROS (Reactive Oxygen Species) dengan salah satu basa dari DNA,bila tidak terjadi perbaikan DNA, maka DNA tersebut dapat mengalami mutasi yang berujung pada keganasan. (2,7-9)

Lipid merupakan salah satu penyusun membran sel berupa asam lemak tak jenuh ganda. Pada lipid, radikal bebas dapat menyebabkan peroksidasi lipid di membran sel. Lipid peroksidasi suatu rantai reaksi degradasi oksidatif di mana radikal bebas mengambil elektron dari lipid di membran sel yang mengakibatkan kerusakan sel. Proses ini berlangsung melalui mekanisme reaksi berantai radikal bebas. Hal ini paling sering mempengaruhi asam lemak tak jenuh ganda, karena mengandung banyak ikatan rangkap di antaranya terletak pada jembatan metilen (-CH2-) yang memiliki atom hidrogen yang sangat reaktif. Seperti reaksi radikal lainnya, reaksi terdiri dari tiga langkah utama: inisiasi, propagasi, dan terminasi. (2,7-9) 
UMI Medical Journal Vol.6 Issue:1 (Juni, 2021)

p-ISSN: 2548-4079/e-ISSN: 2685-7561

Inisiasi merupakan tahap di mana asam lemak radikal diproduksi. Inisiator yang paling banyak dalam sel adalah Reactive Oxygen Species (ROS), seperti OH · dan $\mathrm{HOO} \cdot$, yang dapat bergabung dengan atom hidrogen menghasilkan air dan asam lemak radikal. Asam lemak radikal bukan merupakan molekul yang stabil sehingga mudah bereaksi dengan molekul oksigen, dan menciptakan asam lemak radikal peroksil. Radikal ini juga merupakan spesies tidak stabil yang bereaksi dengan asam lemak bebas lainnya, menghasilkan asam lemak radikal dan lipid peroksida yang berbeda, atau peroksida siklik jika ia bereaksi dengan dirinya sendiri. Ketika radikal bereaksi dengan non-radikal, akan selalu menghasilkan radikal lain, oleh karenanya proses ini disebut "mekanisme reaksi berantai". Reaksi radikal berhenti ketika dua radikal bereaksi dan menghasilkan spesies non-radikal. Hal ini terjadi jika konsentrasi spesies radikal cukup tinggi sehingga memungkinkan terjadinya tabrakan antara dua radikal. (2,7-9)

\section{Hubungan Antara Obesitas dan Stress Oksidatif}

Obesitas dapat menimbulkan keadaan stres oksidatif karena adanya ketidakseimbangan antara radikal bebas dengan antioksidan di dalam tubuh. Terdapat beberapa kondisi pada obesitas yang dapat memicu stress oksidatif, diantaranya: Hiperglikemik, hiperlipidemia, chronic low grade inflammation, hiperleptinemia, peningkatan aktifitas otot, dan disfungsi endotelial.

\section{Hiperglikemia}

Kelebihan glukosa intraseluler meningkatkan jalur glikolisis dan siklus asam sitrat yang menyebabkan kelebihan produksi NADH dan FADH2 sehingga terjadi peningkatan gradien proton yang melintasi membran bagian dalam mitokondria yang menyebabkan kebocoran elektron pada kompleks III yang berujung terbentuknya superoksida. Radikal bebas yang terbentuk menghambat enzim dehidrogenase gliseraldehida-3-fosfat sehingga mengarahkan metabolit antara glukosa ke dalam empat jalur alternatif: (1) glukosa dialihkan ke jalur poliol; (2) fruktosa-6-fosfat dialihkan ke jalur heksosamin; (3) triose fosfat menghasilkan metilglioksal, prekursor utama Advanced Glycation Endproducts (AGE); dan (4) dihydroxyacetone phosphate diubah menjadi diacylglycol, yang mengaktifkan jalur PKC. Aktivasi jalur alternatif ini menginduksi stres oksidatif / nitrosatif baik dengan meningkatkan produksi radikal bebas atau dengan merusak pertahanan antioksidan. Aktivasi jalur poliol menyebabkan penipisan NADPH dan meningkatkan konversi glukosa menjadi sorbitol, yang kemudian mengaktifkan beberapa stress gene dan menyebabkan stres oksidatif. Pembentukan glukosamin-6-fosfat dalam jalur heksosamin menghambat aktivitas thioredoksin dan menginduksi stres oksidatif dan stress retikulum endoplasma (ER). AGE dan PKC merangsang produksi ROS / RNS dengan mengaktifkan NOX dan NF-kB. Aktivasi enzim NOX meningkat produksi radikal superoksida $\left(\mathrm{O}_{2}{ }^{-}\right)$dengan mengkatalisasi reduksi oksigen menggunakan NADPH sebagai donor elektron internal. Glukosa auto-oksidasi juga menghasilkan oksidasi reaktif mirip dengan radikal hidroksil dan superoksida. AGE berikatan dengan reseptor permukaan sel khusus yang 
UMI Medical Journal Vol.6 Issue:1 (Juni, 2021)

p-ISSN: 2548-4079/e-ISSN: 2685-7561

menyebabkan modifikasi pensinyalan post-reseptor dan menyebabkan terbentuknya ROS. Aktivasi faktor transkripsi NF-kB membentuk beberapa molekul adhesi (E-selectin, molekul adhesi antar-1, dan endotelin-1), sitokin proinflamasi (TNF- $\alpha$ dan IL-6), iNOS, dan microRNA yang terlibat dalam adipogenesis, inflamasi, dan stres oksidatif.

\section{Hiperlipidemia}

Obesitas dikaitkan dengan peningkatan asam lemak bebas (FFA) serta penyimpanan lemak berlebihan di WAT ( White Adipose Tissue). Peningkatan FFA plasma dapat meningkatkan pembentukan $\mathrm{O}_{2}{ }^{-}$pada transport elektron di mitokondria dengan menghambat translokasi adenin nukleotida. FFA merangsang produksi mediator reaktif melalui aktivasi NOX pada $P K C$-dependent dalam sel-sel pembuluh darah yang dikultur. Asam lemak terkonjugasi rentan terhadap oksidasi, sehingga merangsang pembentukan radikal dan meningkatkan akumulasi produk sampingan oksidatif. Furukawa et al. menemukan bahwa penumpukan lemak berlebih pada WAT menyebabkan peningkatan peroksidasi lipid pada WAT itu sendiri. Dalam penelitian pada hewan, diamati bahwa obesitas meningkatkan aktivitas NOX dan menurunkan ekspresi mRNA dan aktivitas enzim antioksidan seperti SOD, katalase (CAT), dan GPx dalam WAT. Asupan makanan dari lipid spesifik juga menginduksi stres oksidatif. Konsumsi asam linolenat terkonjugasi meningkatkan konsentrasi 8-epi PGF2a dalam urin pada pria paruh baya dengan obesitas sentral. (10-12)

\section{Chronic Low Grade Inflammation}

Obesitas merupakan suatu kondisi peradangan kronis, yang merupakan sumber penting lain dari stres oksidatif. Peningkatan kadar biomarker stres oksidatif, telah ditemukan di sejumlah penyakit inflamasi seperti penyakit Crohn dan penyakit rematik. (13) TNF- $\alpha$, IL-6, dan IL-1 adalah mediator yang paling terkenal dari respons inflamasi akut. Baik TNF-a dan IL-6 meningkatkan aktivitas NOX dan produksi anion superoksida. $(14,15)$

\section{Hiperleptinemia}

Obesitas dikaitkan dengan peningkatan kadar leptin plasma. Leptin berperan penting dalam stres oksidatif yang diinduksi oleh obesitas. Hormon leptin mengaktifkan NOX dan menginduksi produksi zat antara reaktif seperti $\mathrm{H}_{2} \mathrm{O}_{2}$ dan radikal hidroksil. Dalam model tikus, injeksi leptin menyebabkan kadar plasma dan lipid hidroperoksida urin yang lebih tinggi, MDA, isoprostane, dan kandungan protein karbon dibandingkan dengan kontrol. $(15,16)$

Selain itu, leptin juga merangsang proliferasi monosit dan makrofag sehingga dapat meningkatkan produksi sitokin proinflamasi. Leptin juga mengurangi aktivitas antioksidan paranoksase-seluler 1 (PON1); pengurangan ini terkait dengan peningkatan kadar 8-isoPGF2a urin dan kadar MDA dan hidroperoksida plasma. $(15,16)$ 
UMI Medical Journal Vol.6 Issue:1 (Juni, 2021)

p-ISSN: 2548-4079/e-ISSN: 2685-7561

\section{Peningkatan Aktifitas Otot}

Pada obesitas, peningkatan aktivitas otot dapat menghasilkan radikal bebas yang berlebihan melalui aktivasi jalur metabolisme, diantaranya peningkatan aktivitas rantai transpor elektron dan perubahan hipoksantin menjadi urat. Konversi hipoksantin menjadi urat dikaitkan dengan pembentukan anion superoksida. Selain itu, pemindahan elektron yang cepat selama peningkatan respirasi dapat menyebabkan kebocoran elektron. Oleh karena itu, pada individu yang mengalami obesitas, terjadi peningkatan laju respirasi seluler dan konsumsi oksigen pada jaringan otot selama aktivitas fisik. Orang yang mengalami obesitas juga secara mekanik mengalami peningkatan pengeluaran energi saat melakukan aktifitas. Peningkatan respirasi mitokondria untuk produksi energi dikaitkan dengan kadar hidroperoksida lipid yang lebih tinggi pada orang obesitas.(17)

\section{Disfungsi Endotelial}

Endotel vaskular merupakan tempat penting bagi enzim yang menghasilkan oksidan, termasuk NOX, xantin oksidase, dan NO synthase. Aktivasi NOX memainkan peranan penting dalam produksi $\mathrm{O}_{2}{ }^{-}$ di endotel. Xanthine oksidase juga bereaksi dengan $\mathrm{O}_{2}$ untuk membentuk $\mathrm{O}_{2}{ }^{-}$dan $\mathrm{H}_{2} \mathrm{O}$. Produksi $\mathrm{O}_{2}$ berlebihan menyebabkan terjadi reaksi cepat dengan NO membentuk ONOO sehingga mengurangi bioavailabilitas NO dan menyebabkan nitrosilasi protein. Enzim NO sintase juga menstimulasi pembentukan $\mathrm{O}_{2}{ }^{-}$yang berlebihan dan ONOO dengan mengkatalisasi elektron transport dari NADPH ke grup heme lain. Aktivitas enzim penghasil oksidan ini dapat dimodifikasi oleh sitokin dan hormon seperti yang ada di renin-angiotensin sistem. Telah diamati bahwa pada hipertensi yang diinduksi angiotensin II, terjadi peningkatan produksi $\mathrm{O}_{2}{ }^{-}$di endotel akibat dari peningkatan aktivitas NADPH-oksidase. $(10,18,19)$

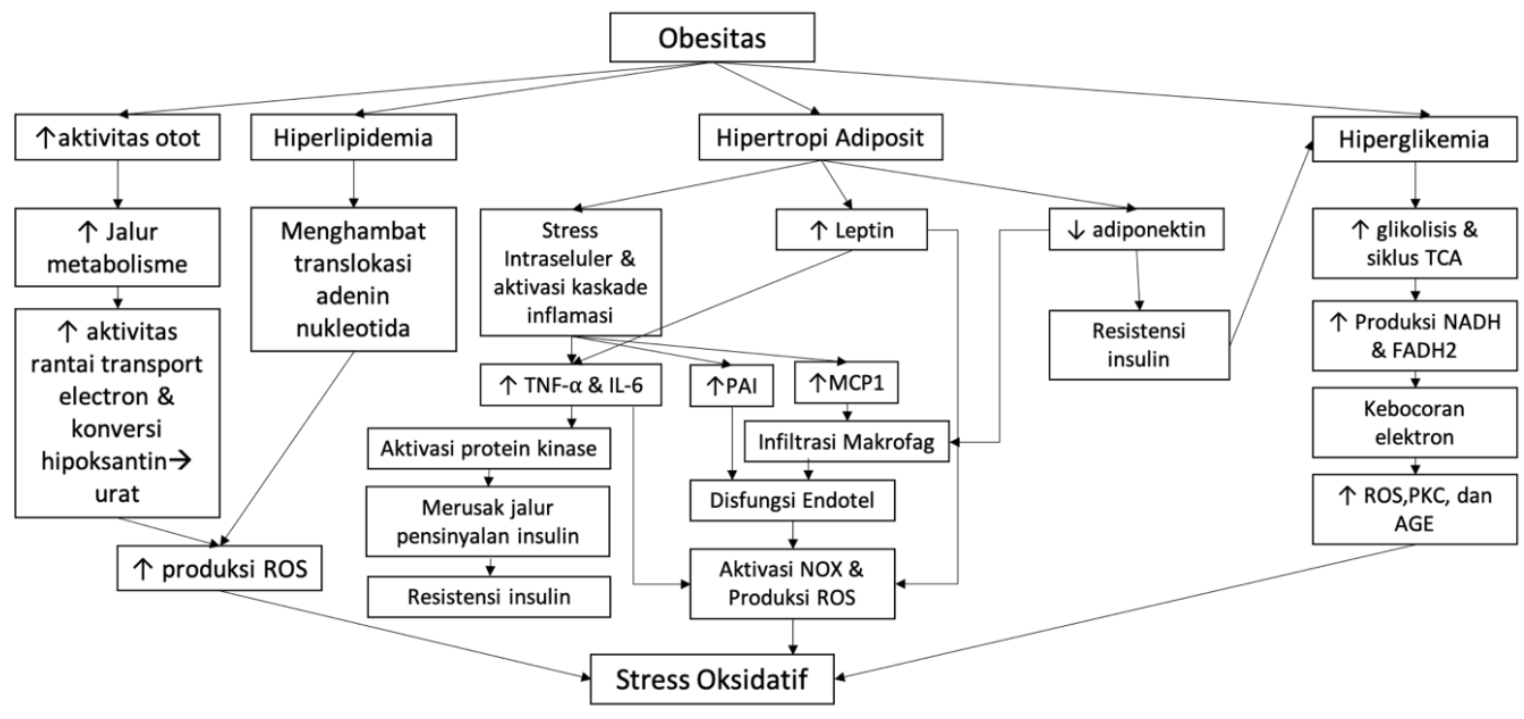

Gambar 1. Hubungan Obesitas dan Stress Oksidatif

KESIMPULAN

Obesitas memicu stres oksidatif disebabkan berbagai mekanisme diantaranya hiperglikemia, hiperlipidemia, Chronic Low Grade Inflammation, hyperleptinemia, peningkatan aktifitas otot, dan 
UMI Medical Journal Vol.6 Issue:1 (Juni, 2021)

p-ISSN: 2548-4079/e-ISSN: 2685-7561

disfungsi endotel. Stres oksidatif yang berlangsung kronik akan menimbulkan berbagai kerusakan di sel dan jaringan yang dapat berdampak negatif pada kesehatan tubuh.

\section{Konflik Kepentingan}

None

\section{Sumber Dana}

Mandiri

\section{DAFTAR PUSTAKA}

1. Irawan R. Hubungan Obesitas terhadap Kadar Malondialdehid (MDA) Plasma pada Mahasiswa Program Studi Pendidikan Dokter UIN Syarif Hidayatullah Jakarta [Skripsi]. 2013;4-12. Available from: http://repository.uinjkt.ac.id/dspace/bitstream/123456789/26403/1/Rico Irawan-FKIK.pdf

2. Sriyanti S, Damayanthi E, Anwar F. Status antioksidan dan oksidatif laki-laki yang mengalami kegemukan dengan pemberian minuman rosela ungu. J Gizi Indones. 2019;7(2):75.

3. Rocha VZ, Folco EJ. Inflammatory Concepts of Obesity. Int J Inflam. 2011;2011:1-14.

4. Kern PA, Di Gregorio GB, Lu T, Rassouli N, Ranganathan G. Adiponectin expression from human adipose tissue: Relation to obesity, insulin resistance, and tumor necrosis factor- $\alpha$ expression. Diabetes. 2003 Jul 1;52(7):1779-85.

5. Lumeng CN, Bodzin JL, Saltiel AR. Obesity induces a phenotypic switch in adipose tissue macrophage polarization. J Clin Invest. 2007 Jan 4;117(1):175-84.

6. Odegaard JI, Ricardo-Gonzalez RR, Goforth MH, Morel CR, Subramanian V, Mukundan L, et al. Macrophage-specific PPAR $\gamma$ controls alternative activation and improves insulin resistance. Nature. 2007 Jun 28;447(7148):1116-20.

7. Gaschler MM, Stockwell BR. Lipid peroxidation in cell death. Biochem Biophys Res Commun [Internet]. 2017;482(3):419-25. Available from: http://dx.doi.org/10.1016/j.bbrc.2016.10.086

8. Niki E. Lipid peroxidation products as oxidative stress biomarkers. BioFactors. 2008;34(2):171-80.

9. Tsikas D. Assessment of lipid peroxidation by measuring malondialdehyde (MDA) and relatives in biological samples: Analytical and biological challenges. Anal Biochem [Internet]. 2017;524:1330. Available from: http://dx.doi.org/10.1016/j.ab.2016.10.021

10. Furukawa S, Matsuda M, Furukawa S, Fujita T, Shimabukuro M, Iwaki M. Increased oxidative stress in obesity and its impact on metabolic syndrome Find the latest version : Increased oxidative stress in obesity and its impact on metabolic syndrome. J Clin Invest. 2017;114(12):1752-61.

11. Fernández-Sánchez A, Madrigal-Santillán E, Bautista M, Esquivel-Soto J, Morales-González Á, Esquivel-Chirino $\mathrm{C}$, et al. Inflammation, oxidative stress, and obesity. Int $\mathrm{J}$ Mol Sci. 2011;12(5):3117-32. 
p-ISSN: 2548-4079/e-ISSN: 2685-7561

12. Matsuda M, Shimomura I. Increased oxidative stress in obesity: Implications for metabolic syndrome, diabetes, hypertension, dyslipidemia, atherosclerosis, and cancer. Obes Res Clin Pract [Internet]. 2013;7(5):1-12. Available from: http://dx.doi.org/10.1016/j.orcp.2013.05.004

13. Basu S, Whiteman M, Mattey DL, Halliwell B. Raised levels of F2-isoprostanes and prostaglandin F2 $\alpha$ in different rheumatic diseases. Ann Rheum Dis. 2001;60(6):627-31.

14. Shen H-M, Pervaiz S. TNF receptor superfamily-induced cell death: redox-dependent execution. FASEB J [Internet]. 2006 Aug [cited 2020 Feb 19];20(10):1589-98. Available from: http://www.ncbi.nlm.nih.gov/pubmed/16873882

15. Manna P, Jain SK. Obesity, Oxidative Stress, Adipose Tissue Dysfunction, and the Associated Health Risks: Causes and Therapeutic Strategies. Metab Syndr Relat Disord. 2015;13(10):423-44.

16. Bełtowski J, Wójcicka G, Jamroz A. Leptin decreases plasma paraoxonase 1 (PON1) activity and induces oxidative stress: the possible novel mechanism for proatherogenic effect of chronic hyperleptinemia. Atherosclerosis [Internet]. 2003 Sep [cited 2020 Feb 19];170(1):21-9. Available from: http://www.ncbi.nlm.nih.gov/pubmed/12957679

17. Vincent HK, Vincent KR, Bourguignon C, Braith RW. Obesity and postexercise oxidative stress in older women. Med Sci Sports Exerc [Internet]. 2005 Feb [cited 2020 Feb 19];37(2):213-9. Available from: http://www.ncbi.nlm.nih.gov/pubmed/15692315

18. Limanan D. Hantaran Sinyal Leptin dan Obesitas: Hubungannya dengan Penyakit Kardiovaskuler. eJournal Kedokt Indones. 2013;1(2).

19. Wolin MS, Ahmad M, Gupte SA. The sources of oxidative stress in the vessel wall. In: Kidney International. Blackwell Publishing Inc.; 2005. p. 1659-61. 